\title{
Successful Strategies to Sustain Profits from Tourism Following a Hurricane
}

\author{
Dr. Kevin C. James ${ }^{1}$, Dr. Dina L. Samora ${ }^{2}$, Dr. Irene A. Williams ${ }^{3}$ iD and Dr. Desire S. Luamba ${ }^{4}$ \\ ${ }^{I}$ DBA, Subcontracts Manager, L3Harris Technologies Inc., Palm Bay, FL-USA \\ ${ }^{2}$ DBA, Faculty Contributor, College of Management and Technology, Walden University, USA \\ ${ }^{3}$ Ph.D. Senior Contributing Faculty Programs, College of Management and Technology, Walden University, USA \\ ${ }^{4}$ Vice President and CEO, Star Light Consulting LLC, Manassas, VA-USA
}

*Correspondence: Dr. Kevin C. James, kcjames787@gmail.com

\begin{abstract}
Hurricanes have caused billions of dollars in damage to the hotel industry in Florida, significantly affecting tourism flow. The unpredictable impact of hurricanes makes sustaining profits challenging. The purpose of this multiple case study was to explore strategies that hotel leaders use to sustain tourism profits following a hurricane. The theory of image restoration provided the conceptual framework for the study. Data was collected from company documents and semi-structured interviews with 5 hotel leaders in Central Florida. Transcribed data were coded then validated using member checking during the data analysis, which revealed 5 themes: storm impact, accommodations, operations, communications, and planning. Results indicated the relevance of the theory of image restoration to help hotel leaders get operations back to normal following a hurricane by emphasizing how effective crisis response strategies can help create opportunities to sustain profits beyond tourism. Results may be used by hotel leaders to sustain profits and support their communities during hurricane recovery by providing accommodations, safety, and security to stakeholders other than tourists, such as first responders, state, and residents.
\end{abstract}

KEYWORDS: Crisis Communication; Organizational Crisis; Resilience; Tourism Crisis; Tourism Industry

\section{ARTICLE INFORMATION}

Author(s): Dr. Kevin C. James, Dr. Dina L. Samora, Dr. Irene A. Williams and Dr. Desire S. Luamba

Received: 03 Aug, 2021; Accepted: 05 Dec, 2021; Published: 10 Dec, 2021; e-ISSN: $2347-4696$;

Paper Id: BMN-IJBMR-2021-56;

Citation: doi.org/10.37391/IJBMR.090409

Webpage-link:

https://ijbmr.forexjournal.co.in/archive/volume-9/ijbmr-090409.html

\section{INTRODUCTION}

Tourism is one of the most economically important global industries, yet its survival relies heavily on the mobility of tourists [1]. Ivanov et al.'s [2] study on the impact of the COVID-19 pandemic demonstrated that even a biosecurity threat exposes the vulnerability of tourism. Nonetheless, in the summer months, one of the biggest impacts to tourism is hurricanes. As climate change, temperatures continue to affect the United States, and coastal communities like those in Florida remain at risk of hurricane impacts [3]. Although the disruptive nature of disasters significantly impacts tourism often costing them billions of dollars of loss [4, 1], there is no greater impact on the industry than lack of preparedness.

Many tourism operators lack the resources and capabilities to rebound [5]. Consequently, the complex relationships between causes and effects, and decisions and actions are difficult to understand in tourism-related subsidiaries like hotels. Hotel managers may use the information from the current study to integrate crisis and strategic management practices to sustain their businesses [6]. Previous researchers concluded that managers need the ability and skills to deal with the aftermaths of natural disaster to sustain their business sustainability $[7,8]$. To repair or restore the image, maintain the value of the business, and gather valuable information on how to implement strategies to sustain profits from tourism following a hurricane may be challenging for hotel leaders.

\section{BACKGROUND}

Florida is always affected by a hurricane every year, and this threat has made Florida one of America's most vulnerable states due to the high impact of storms on business activities [9, 10]. Zampieri et al. [11] noted that the unpredictability of hurricanes has a serious negative impact on tourism businesses and activities accounting for billions of dollars in losses. Many tourism activities have even definitively closed due to a lack of customers, financial resources, and strategies to rebound $[12,5]$. Consequently, determining the real causes and effects, and planning decisions and actions to undertake when face with hurricanes consequences has become complex to tourism businesses like hotels, bars, restaurants, and recreation centers which already have other business challenges. Tourism business managers may use the findings of this analysis to integrate hurricanes crises and strategies to sustain their business activities over time [6]. Many researchers analyzed the impact of tourism activities on business profitability and sustainability; however, less attention was paid to hotel managers' strategies to improve decision-making following a hurricane $[9,13,11]$.

\section{CONCEPTUAL FRAMEWORK}

The conceptual framework for this study was the theory of image restoration. Benoit [14] developed the theory of image restoration in 1995 as an approach for developing an understanding of messaging when responding to corporate image crises. A crisis has the potential to destroy a brand, and in recent years National economies have experienced a series of global crises that is inconsistent with brand values $[15,16]$. 
Ketter [17] mentioned that according to the image repair theory, cultivating and protecting a destination's image from a crisis is critical for business longevity.

The proper use of image restoration strategies is to avoid the blame game [7]; therefore, it is important to point out that there is a lasting risk associated with perceived negative events regardless of the mitigating factors [15]. The theory of image restoration holds that communicators who need to restore damaged reputations have five strategic options: denial, evading responsibility, reducing offensiveness, corrective actions, and mortification [14], which provides organizational leaders with message strategies to sustain profits following a natural disaster such as a hurricane.

\section{LIMITATIONS}

Yin [18] described limitations as circumstances beyond the control that a researcher needs to master because they may affect the analysis and findings of the research. The key limitations of this study included (a) the proximity of the participants to where hurricanes make landfalls such as inland versus coastal areas, (b) the scope of research in Central Florida extending from the coast to inland areas, and (c) the number of hotel leaders willing to participate in the study. Additionally, there may be different guidelines and local regulations used to govern hotel safety and security systems, and privacy restrictions could have limited access to archival data requested from participants.

\section{LITERATURE REVIEW}

A crisis can be human-made or the result of a natural disaster [19]. Mirvis [20] defined a crisis as a series of unforeseen events that come out of nowhere with no limitations on the level of chaos that can affect organizations. Many scholars pointed out that crises such as terrorist attacks, hurricanes, pandemics, tsunamis, earthquakes, power outages, and economic crises can occur with or without warning signs, and more importantly, they can quickly shatter societies and arouse trans-regional attention or lead an organization's reputation into a downward spiral which can significantly affect their profitability efforts $(7,21,8,22,1]$. Even though the magnitude of damage from crises is often unpredictable, reported weather conditions help give organizations and communities' warnings of an approaching event.

Failure to predetermine damages does not relieve responsible actors of the burden of responsibility. Scholars recommend that hotel managers understand various factors such as tourism safety, tourist decision-making, emergency preparedness, crisis knowledge, crisis management, corporate social responsibility, the risk associated with unexpected humanmade or natural disasters, and sustainability efforts in the hotel industry to remain competitive [23, 9, 24, 25]. Various researchers have shown that managers or leaders who have used various marketing initiatives and resources like local media and social media have improved safety measures, promoted the image of the business, and increased profits [26,27, 9, 28, 29]. Hotel managers who formulate effective message strategies to deal with crises demonstrate their assertiveness to mitigate the negative fallout [14, 30, 9].

\subsection{Benoit's Theory of Image Restoration Theoretical Framework}

Organizational leaders are not immune from crises, and their response to a crisis can affect their business reputation and image. Zenker and Kock [31] noted that any human-made or natural disaster can generate a crisis that could have a negative influence on the tourism industry and threaten companies' ability to attract tourists. For example, researchers showed how the impact of Hurricane Katrina disrupted the economic infrastructure, image, and ability of New Orleans, Louisiana to be an attractive tourist destination immediately following the hurricane, causing businesses to close and loss of jobs [32, 33, 34]. Similarly, the COVID-19 pandemic, Texas power outage, Afghanistan Troop withdrawal, and other natural disasters like fires and earthquakes all poses risk to the tourism industry both locally and globally $[7,35,1]$. Destination marketers have used several strategies to reduce the negative impact of disasters or crises by highlighting areas not affected and conducting rapid cleanup and rebuilding efforts, which positively affected the perceptions of tourist destinations [9, 24, 32]. Some authors believed that organizations could tailor their crisis communication strategies depending on the crisis type and consumer reactions [33, 34]. Kim [36] mentioned that crisis communication researchers tend to view a company's crisis communication strategy from a success or failure standpoint. The theory of image restoration provides a response strategy that is designed to increase success and mitigate failure.

Crises are often unpredictable, but an organizational leader's response does not have to be unpredictable. An organization's ability to respond to a crisis can affect its brand image; thus, the backward-looking strategic approach of the theory of image restoration enables corporations to understand crises by focusing on message options [14, 36, 32]. Favorable crisis response options offer a leader the ways to reduce the negative impact on a destination's image, mainly when they understand how, when, and where to employ it. There is no straightforward approach to respond to a crisis. When a crisis occurs, unbeknownst to an organization, the public will immediately seek to attribute blame; therefore, organizations must act swiftly and efficiently with how, when, and what type of information to disseminate. Some authors concluded that leaders should act responsibly to enhance tourism resistance, strengthen organizational defense mechanisms, and limit the time it takes to return to normalcy $[12,13,10]$. The theory of image restoration proposes five messaging strategies for crisis responses that can be used in different situations, which include denials, evasion of responsibilities, reducing offensiveness of events, corrective actions, and mortifications or forgiveness $[14,37,38]$. The first options suggest a leader's unwillingness to accept responsibility for the outcome.

\subsubsection{Denial}

When crises occur, people tend to point fingers, assign blame, or deny responsibility. Many researchers posited that denial 
could be achieved by rejecting accusations and implicating someone else or challenging the verity behind assumptions regarding negative events $[14,38]$. For example, professional baseball player Barry Bonds shifted the blame for his alleged steroid use to his strength trainer, essentially denying any responsibility for the allegations [39]. In a crisis, there are alleged offenders and victims. Hearit and Roberson [40] argued that denial is an effective response strategy if the intended audiences accept it. Denial may not be feasible in every instance; however, it offers a response strategy that could go either way.

\subsubsection{Evading responsibility}

In the early stages of a crisis, it could be difficult to determine which response strategy an organization will choose. The organizations that evade responsibility project an image that rejects culpability and blurs the lines between control and intentions, which allows them to counteract negative perceptions [14, 41, 39]. For example, the Arab Spring and other violent governmental uprisings, political tensions, and terrorist attacks significantly affected the tourism brand of the Middle East because countries denied and evaded responsibility costing the region over $\$ 15$ billion in revenues [42, 43]. The intentional acts of individuals or groups can make evading responsibility difficult. Marsen [44] noted that the threat to an organization's reputation increases or decreases based on the degree of communication and the acceptance of responsibility; therefore, Stone et al. [45] suggested that it is appropriate to blame crisis provocations on others if the company or industry is not able to sway public opinion against any wrongdoing. As shown in the Middle East, that could be difficult, so when evading responsibility is not feasible, reducing offensiveness may be the next viable option for organizations to use [43, 45].

\subsubsection{Reducing of offensiveness}

In any crisis, one of the first acts should be to get a handle on what is happening. An organization's ability to reduce offensiveness strengthens its positive image by bolstering, minimizing, differentiating, transcendence, attacking, or compensation [14, 37]. British Airways reduced the offensiveness following the crash of their Boeing 777 by utilizing media resources to frame the incident in a positive light. They used a series of tactics such as the release of a predraft statement describing the flight details, providing instructions on the company's website for passengers and guests, and placing the Chief Executive Officer (CEO) out front to praise the team for their responses [9]. Similar to British Airways' success to reduce the offensiveness, Arby's utilized the strategy to improve its reputation after an aggressive advertising campaign strayed away from its intended message. In this case, local Iowans felt attacked by Arby's after they attempted to smear the reputation of Subway about fresh meat slices, prompting Arby's for utilizing Benoit's reduction of the offensiveness strategy $[14,8]$. Leaders may find that reducing the offensiveness of a crisis has many characteristics. In any event, reducing offensiveness does not deny or evade responsibility, instead, it permits organizations to accept responsibility. The final two steps of the typology take on a more active role by indicating that a leader has taken responsibility for their action.

\subsubsection{Corrective actions and mortifications}

Taking actions to mitigate the negative impact of a crisis should be swift and effective. It is helpful when a leader is acutely aware of the crisis and those involved. Researchers warned leaders that the use of one image restoration strategy is not a mean for disregarding the possibilities of combining strategies [46, 47]. Forester et al. [47] argued that corrective actions and mortification embrace both responsibility and the reprehensible nature of the act. Corrective actions involve efforts to repair damaged reputations, and mortification seeks forgiveness for the offense [14, 9]. The unpredictability of a crisis can lead to unpredictable responses; however, Brown et al. [27] suggested that when planning for disasters leaders should focus on communication to mitigate, prepare, respond, and recover; thus the options available in Benoit's typology helps provide a framework for hotel leaders to sustain tourism profits following a hurricane.

\subsection{Tourism and Hotel Industry}

Elements of the tourism and the hotel industry rely upon each other for success. Some authors characterize the tourism industry as a diverse sector of public and private businesses comprise of an open system functioning as the pillar of economic stimulation consisting of the forms, types, and versions of historical and cultural systems that help create economic, social, and cultural recovery opportunities from field activities like hotels, restaurants, travel agencies, and government and non-governmental bodies [9, 48]. PerssonFischer and Liu [48] described the hotel industry as an industry that provides residential accommodations, creates jobs, promotes developments of tourism activities, and improves the welfare of residents in tourism areas that help revive economies. As with any industry, the tourism and hotel industry are not free from crises. When tourism and hotel leaders learn from past events, it helps them assess the benchmarks these industries demand. The effects of crises on the hotel industry impact far more than tourism itself. One of the most significant challenges that hotel leaders will encounter involves determining when, why, and what they would characterize as an event in a crisis [9].

Sharma and Tham [49] noted that intangible damages that crises have on service and infrastructure are difficult and severely affect tourism flow. Tourists perceived threats differently, and it could be difficult to determine which threat poses the biggest challenge. When tourist regards an area as at risk to their public safety it could hinder both organizations and communities from sustaining tourism profits. The responsibility to address these perceived threats typically falls on tourism managers. When disasters occur, such as hurricanes, organizations should adopt new behavioral responses when there are apparent failures in place [9]. A hurricane is defined as a tropical cyclone with winds over $74 \mathrm{mph}$ with deep convection generated by hot sources of warm upward and downward drafts from the earth's surface $[50,51]$. In many cases, prior knowledge about hurricanes 
should help with planning; nevertheless, the fact that hurricane severity and timing are unpredictable makes it difficult for leaders in the hotel and tourism industry to predict impacts. Timely and adequate corporate responses restore consumer confidence and help mitigate negative perceptions of a company's messaging strategy $[9,49]$.

When it comes to natural disasters since the 20th-century highimpact weather events like hurricanes have caused significant disruption to Florida's hotel and tourism industry resulting in over $\$ 450$ billion in damages [46, 47]. Similarly, a hurricane has caused significant damage in other areas such as North Carolina and Louisiana [52, 9]. Regardless of disaster impacts, crisis planners' initiatives should use the perception of those in the tourism industry as a strategy to develop effective plans to mitigate the impact on hotels $[53,54]$. Benoit's theory shows that no matter the factors that cause the crisis, it does not prevent audiences from assigning blame [14]. Whether actions are proactive or reactive, leaders need to act. Hotel leaders should review their organization's internal and external resources to prepare for various crises, including hurricanes.

\subsection{Emergency Preparedness}

In many cases, leaders who critically assessed their internal and external infrastructure may discover areas of weaknesses, which may warn of a potential crisis. When early warning signals or crisis signals deviate from normalcy, crises can escalate [29, 31]. Lupo [29] argued that regular assessments of hurricane risk and evacuation procedures should be prepared to address different types of tourists. A leader's ability to detect, plan, and disseminate information is critical to the relationship and reputation between an organization and its stakeholders. Organizational leaders must understand how to merge or develop strategies to communicate effectively in the event of a crisis. One way to consolidate and establish strategies is to evaluate what others have done.

It can be difficult for hotel leaders to determine what to focus on when hurricanes impact their business sector. Some authors argued that it is essential to prepare plans to reduce risk in areas that rely heavily on tourism and arise from natural disasters [9, 17]. Tsai et al. [55] argued that during emergency catastrophe organizational leaders should have proper safety measures, emergency preparedness plans, leadership, coordination, and sufficient resources to respond positively to any catastrophic situation and prevent business failure. Martin and Hall [32] argued that having a clear understanding of the emergency plans before a disaster may help leaders know which attributes to focus on during recovery. In tourism, crisis disasters and communication efforts help rebuild consumer confidence [56].

A hurricane crisis or any other crisis that affects the hotel and tourism industry does not mitigate a company's responsibility to remain competitive. A leader's ability to remain competitive in the hotel and tourism industry requires that they take a holistic view of themselves and their crisis management efforts. James [9] argued that integrating crisis management into the strategic management of organizations depends on innovative and intuitive strategies to survive and flourish. Other authors concluded that planners who are actively engaged in recovery planning could reduce damage images, reputations, and tourist behaviors [44, 49]. With more than $50 \%$ of U.S. landfalling tropical cyclones hitting Florida, the risk posed to a tourist is higher than the risk to non-tourist [57]. Managing corporate communication using a crisis response strategy can limit adverse effects [58]. As shown in the cruise industry, when corporations are not out in front of a crisis the fallout has global implications [59]. The choices used within Benoit's typology may indicate an organization's willingness to preserve what remains from a damaged reputation [14, 9, 24, 29]; however, hotel leaders should seek to reduce the impact of hurricanes by expanding their roles within the industries and communities they serve.

\subsection{Corporate Social Responsibility}

Organizational leaders need to act responsibly for the conduct, products, and services provided by their organizations within a business environment [9, 29]. Chan et al. [60] described corporate social responsibility (CSR) as the willingness to pay extra for products with CSR attributes. In the hotel and tourism industry, when firms elect to address CSR concerns, it could help differentiate them from their competition. The inherent benefit of stakeholders engaged in CSR is the investment links affecting market practices that improve corporate reputation, brand image, and customer relationships $[60,61]$. A major part of the CSR initiative should include messaging strategies capable of handling crisis response.

The tourism industry is a key driver of global socioeconomic progress, but the risks of multiple shocks and hazards are tremendous challenges the industry face $[10,11]$. When hotel leaders consider all the stakeholder's needs in the tourism industry, they can properly plan and prepare for the slow or sudden changes that take place before and after a crisis. The constant influx of tourists and residents in and out of hotels and tourism locations is hard to determine. Several authors asserted that as the global tourism system goes through changes, there would be a growing need to develop techniques to respond to these challenges $[12,9,29]$. Awareness of these trends will help organizations develop an effective response strategy in the event a natural disaster such as hurricanes affects the market, which may also affect profit.

Hotel leaders need to make money to remain in the marketplace, and more importantly, these efforts must be sustainable. Some authors believed that in the event of a crisis, tourist behavior would likely be affected; therefore, combining resources help create value $[8,9,29]$. The tourism industry acts as a vehicle that supports tourists and residents because of the requirement of hotel stays in the event of a hurricane, or any other human-made or natural disaster. Consequently, sustainability brings heritage preservation, tourism, and economic development into balance, and as a result to achieve a sustainable competitive advantage requires an understanding of tourism service orientations and the characteristics that produce a profit $[50,47,51]$. A leader's abilities to prepare, recover, and diversify from the impact of a crisis enable organizations to remain competitive in the marketplace [9]. If leaders take proactive approaches to improve their crisis 
management plans, these initiatives can help hotel leaders sustain tourism profits following a hurricane.

\section{METHODOLOGY AND DESIGN}

The research method for this study was qualitative. Yin [18] recommended using a qualitative methodology while using the people-oriented approach to enable researchers to better understand and explore the phenomenon analyzed through interviews. Yin [18] also recommended researchers use other methodologies such as quantitative and mixed methods. Quantitative methodology was not suitable because researchers use a quantitative method to analyze hypotheses and numerical data using surveys or questionnaires which was not the case in this study. Moreover, the mixed method which is a combination of the quantitative and qualitative methodology was also not suitable because we did not explore numeric data or use surveys or questionnaires for this study. Then, to explore the successful strategies of leaders in the hotel industry following a hurricane, we used face-to-face interviews with 5 participants who voluntarily accepted to be part of this study.

The design of this study was a multiple case study. Santos et al. [62] recommended using the case study design because it requires direct observations and interviews of more than one individual involved in the phenomenon. Other designs such as phenomenological design, which involves describing people's lives, or narrative which elicits stories using conversational interviews prompting a process of reflection of a person's experience were not appropriate for this study.

\section{METHOD}

\subsection{Population and Sampling}

In this qualitative multiple case study, the purposive sample included 5 organizational leaders in the hotel industry located in Central Florida who demonstrated the use of successful strategies to sustain tourism profits following a hurricane. Yin [18] argued that researchers should use purposeful sampling to identify and select credible information. Saldana [63] added that the sample size should rest on shared methodological principles for estimating an adequate number of participants to meet data saturation. As recommended by Yin [18], we also used member checking, transcript review, and triangulation to ensure the credibility and validity of the findings. The eligibility criteria for participants in this study were (a) a minimum of 5 years of experience in the hotel industry in Central Florida and (b) having demonstrated successful strategies of profit sustainability from tourism following a hurricane.

\subsection{Procedures}

The research question was: What strategies do organizational leaders in hotel businesses use to sustain tourism profits following a hurricane? And Interview Questions were: (a) What was your experience with dealing with a hurricane as a hotel business leader? (b) What strategies did you use to sustain a profit from tourism following a hurricane? (c) What method did you find worked best to sustain a profit from tourism following a hurricane? (d) How do you determine whether your strategies used to respond to hurricanes are working? (e) What makes dealing with a hurricane challenging for the hotel industry? (f) What, if anything, would you do differently if you were faced with a similar situation? (g) What else could you add to assist others in learning more about ways to sustain a profit from tourism following a hurricane?

Data were primarily collected from semi-structured interview questions-responses with participants. Before conducting the interview, we explained to participants the goal of this study and obtained their consent to freely participate in this study. For the research objectivity, all participants had the same interview questions and the same time of the interview (30 minutes). All Interviews were recorded, and we encouraged participants to ask questions to avoid misinterpretations and misunderstandings. We also used member checking to verify transcripts and ensure data interpretation and transcript reviews were accurate. For privacy and confidentiality, participants' information and data were secured and coded using P1, P2, .., P5 codes.

\section{DATA ANALYSIS}

Following the interviews, we used NVivo, a qualitative data analysis software program, to help analyze the results into themes using codes in an alphanumeric format $[64,65,66]$. Interviews were coded to protect the identity of participants. Table 1 contains participants' professional backgrounds, and table 2 indicates their experiences with hurricanes.

Table 1: Professional Background of the Participants

\begin{tabular}{lcc}
\hline Participant responses & $\begin{array}{l}\text { Years of } \\
\text { experience }\end{array}$ & $\begin{array}{l}\text { Percentage of } \\
\text { totals }\end{array}$ \\
\hline 5 years, but less than 10 & 2 & $40 \%$ \\
More than 10 years & 3 & $60 \%$ \\
Total & 5 & $100 \%$ \\
\hline
\end{tabular}

Hurricanes are not new to Central Florida or any of the southern parts of the United States. According to the National Oceanic and Atmospheric Administration [67], in 2017 there were 17 named storms, 10 of which became hurricanes, and three affected the state of Florida. All participants served in a leadership role for 5 years or more in the hotel industry in Central Florida (see Table 2). $80 \%$ of participants had experienced more than one hurricane as a hotel business leader (see Table 2).

Table 2: Hurricanes Experienced by Participants

\begin{tabular}{lll} 
Hurricanes experienced & Quantity & $\begin{array}{l}\text { Percentage of } \\
\text { totals }\end{array}$ \\
\hline One & 1 & $20 \%$ \\
Two, but less than five & 4 & $80 \%$ \\
More than five & 0 & \\
Total & 5 & $100 \%$ \\
\hline
\end{tabular}


We also used methodological triangulation for the reliability and validity of our findings.

\section{RESULTS}

The five major themes that emerged from NVivo 12 were (a) storm impact, (b) accommodations, (c) operations, (d) communications, and (e) planning.

Theme 1: Storm Impact. The tourism industry is far from static, and the hotel sectors of the tourism industry are vulnerable to a variety of natural and human-made hazards, which pose risks to staff and guest safety, as well as operations and profits $[27,8,24,10]$. The interview data from the current study showed that dealing with hurricanes was not an easy task. The first theme that emerged highlighted the physical, emotional, and mental toll of the storm's impact. All participants spoke of the levels of stress caused by hurricanes, and they stressed the importance of attending to staff, guest, community, and their families, which supported corrective action and mortification messaging options from to conceptual framework (theory of image restoration). Nevertheless, one participant warned, “...if a hotel underperformed before a storm, there was a strong possibility that the impact of the storm would compound problems." A hotel's infrastructure should be a concern for hotel leaders. Moreover, participants suggested that leaders should also consider the infrastructure of their employees. Miller et al. [68] warned that to be successful at rebuilding a destination's image, leaders must address tourists' emotional needs and satisfy their basic needs like food and accommodations.

Theme 2: Accommodations. As indicated by participants, hurricanes can impact tourists and the hotel industry differently. However, hurricanes create business opportunities in other areas. P3, P4, and P5 indicated if he had to do it all over again, he would research how to deal with certain types of clients. Many first responders and residents required accommodations following the storm, yet hotels' lack of planning limited their options. Cordner and Ellingham [69] pointed out that providing emergency relief to a disaster is an essential task for local first responders, which forces local command structures to allocate responsibilities. All participants accommodated various types of first responders: local law enforcement, Red Cross, Army, Disaster Relief, Federal Emergency Management Agency (FEMA), Florida Power and Light, and numerous other agencies from inside and outside the state seeking to help put the community back together, but many struggled with FEMA clients. All participants noted that the storm creates demand due to displaced individuals who enabled them to operate at full occupancy, but they noted the low number of tourists. Additionally, they warned that when it comes to accommodating first responders, your profits will suffer because these agencies are not going to pay top dollar. The focus of proving accommodations helped both the hotel and the community by demonstrating a robust image restoration strategy, particularly the reduce the offensiveness option of Benoit's typology that helps preserve these organizations' image $[14,68]$.
Theme 3: Operations. Hurricanes can severely impact hotel operations, particularly when evacuation orders are mandatory for the location where the hotel operates. Brown et al. [27] mentioned that hotel management and staff must be able to cope with the risk associated with business, guest, and surrounding areas that the disaster effect. The findings in the current study indicated that each of the participants focused on different aspects of hotel operations following the hurricane, yet much of their actions did not focus on making a profit; rather the building of relationships and adhering to their CSRs for the communities they served. The findings forced some to run their operations manually for a couple of days by using old methods like registration cards and excel spreadsheets to prepare for displaced residents and incoming guests. Several participants stressed the importance of understanding the time and details required to close and secure a hotel. Similarly, Participant 2 recommended the use of a third-party agency to provide additional security for facilities in anticipation of the loss of power.

Theme 4: Communication. All participants stressed the importance of communication before, during, and after a hurricane. The findings in the current study demonstrated how hotel leaders use social media, news media, home, and cell phones, as well as the Tourism Development Council to relay messages to staff and guests throughout the storm. P1, P2, P3, and P5 advised, "Leaders should know that communication with first responders and insurance agents before hurricane season helped with addressing accommodation concerns, specifically by letting them know the hotel was prepared to assist them." Additionally, the finding showed that when local hotels go offline, a prior communication with their brands or corporate offices can help facilitate information about the hotel's status for concerned guests on the hotel's behalf. All of the participants indicated the importance of a properly trained staff, and the vitality of remaining in contact with them, whether via cell phone or social media. Miller et al. [68] mentioned that it is not easy to rebuild devastated tourist destinations; however, planning before the occurrence is beneficial to those managing it.

Theme 5: Planning. The findings showed that different hotels have different procedures, yet the good thing about hurricanes is that it gives hurricane leaders time to plan. Though all the participants of this current study spoke of having multiple meetings several times a week leading up to the storm P2, P3, P4 and P5 noted, "Start planning for hurricane season as early as April and May." The findings in the current study supported all participants' recommendations to contact or have relationships established with hotel headquarters, insurance companies, and emergency crews (first responders) before hurricane seasons, specifically, by letting them know your hotel wants to be their preferred customer. Additionally, the findings showed it is important to reach out to alternative agencies. Although Benoit's typology offers five messaging strategies, the participants in this study never denied or evaded responsibility.

\section{DISCUSSION}


The results revealed strategies surrounding hurricane responses that hotel leaders and tourism operators can consider when seeking to understand (a) storm impacts, (b) accommodations, (c) operations, (d) communications, and (e) planning when tourism profits decrease in disaster-prone areas. The principal implication for hotel leaders was when tourism profits decreased due to natural or man-made disasters their efforts to provide accommodations, safety, and security to first responders, state, and residents following a hurricane enabled organizations to sustain profits and support their communities during recovery.

The findings of the current study can facilitate the actions of hotel leaders, tourism operators, and hospitality professionals. Based on the findings, we urge hotel leaders to use the best practices and strategies identified in this study to minimize the adverse effects of hurricanes on tourism profits. Even though the hotel industry is a relatively small sector in the overall hospitality and tourism industry, tourism operators and destination managers can benefit from the findings.

One of the first actions hospitality professionals should be aware of is the difficulty of predicting a hurricane's impact. Consequently, hotel leaders should ensure they formulate, implement, rehearse, update, and be flexible with their crisis management plans, while ensuring all staff members are familiar, equipped, and trained with the contents necessary to execute it. Once leaders create crisis communication plans, they should look to collaborate with other stakeholders to enhance their plans.

Accordingly, leaders need to establish and build rapport with community partners, first responders, the federal government, and other agencies. These individuals and groups can compensate for the loss of tourism revenue caused by the crisis. Finally, communication is paramount; therefore, hotel leaders should ensure communication is effective before, during, and after a crisis. Organizational leaders should (a) identify communication methods, (b) assess their vulnerabilities during a hurricane, (c) share information with community partners, and (d) manage their reputational damage.

The results of this study are significant to hotel leaders' ability to sustain profits following a hurricane. Dissemination of these findings for hotel and tourism leaders will maximize their crisis planning initiatives and improve revenue streams.

\section{CONCLUSION}

Hurricanes threaten the state of Florida every year, which can have a negative effect on hotels and a tourism destination's image. Although disasters pose a risk to a hotel's ability to operate and sustain profits, they have been known to help reduce disaster risks. The purpose of this qualitative multiple case study was to explore strategies that hotel leaders use to sustain tourism profits following a hurricane. As tourism is a significant income generator, the result of this study showed the tangible and intangible ways hotel leaders sustained profits following a hurricane from other resources.
Consequently, the findings from this study concluded that when hotel leaders use both preventive and proactive measures to restore damaged reputations following a hurricane, it opens the doors to a new opportunity. Robust crisis management and response plans may help keep leaders engaged with stakeholders and their communities to sustain or rebuild a positive image. Although no one crisis response strategy works for every single crisis; not having one almost assures the chances of damaged reputations. A positive image of a brand and profit sustainability interconnects in all industries; nevertheless, leaders must not lose sight that the impact of a single crisis can destroy it all.

\section{REFERENCES}

[1] Sharma, G. D., Thomas, A., \& Paul, J. (2021). Reviving tourism industry post-COVID-19: A resilience-based framework. Tourism Management Perspectives, 37(100786), 1-11.

[2] Ivanov, S. H., Webster, C., Stoilova, E., \& Slobodskoy, D. (2020). Biosecurity, crisis management, automation technologies and economic performance of travel, tourism, and hospitality companies: A conceptual framework. Tourism Economics, 1-24. doi:10.1177/1354816620946541.

[3] Zolnikov, T. R., Garces, K. P., Bolter, K., McGuigan, K., \& King, R. K. (2020). Enhancing public health preparedness, response, and recovery capabilities through the Florida Hurricane Response Hub. Climate Risk Management, 30, 1-5. doi:10.1016/j.crm.2020.100251

[4] Filimonau, V., \& Coteau, D. D. (2019). Tourism resilience in the context of integrated destination and disaster management (DM2). Wiley, 1-21. doi:10.1002/jtr.2329.

[5] Mair, J., Ritchie, B. W., \& Walters, G. (2016). Towards a research agenda for post-disaster and post-crisis recovery strategies for tourist destinations: A narrative review. Current $\begin{array}{llll}\text { Issues in } \quad \text { Tourism, } & \text { 19(1), }\end{array}$ doi:10.1080/13683500.2014.932758

[6] Varelas, S., \& Apostolopoulos, N. (2020). The implementation of strategic management in Greek hospitality businesses in times of crisis. Sustainability, 12(17), 7211.

[7] Aspriadis, N. (2021). Image restoration strategies for the (mis) handling of COVID-19 Pandemic in Greece. Proceedings of the International Crisis and Risk Communication Conference, 4, 5659. doi:10.30658/icrcc.2021.14.

[8] Evans, N. G. (2016). Sustainable competitive advantage in tourism organizations: A strategic model applying servicedominant logic and tourism's defining characteristics. Tourism $\begin{array}{llll}\text { Management } & \text { Perspectives, } & 18, & 14-25 .\end{array}$ doi:10.1016/j.tmp.2015.12.015

[9] James, K. C. (2018). Successful Strategies to Sustain Profits from Tourism Following a Hurricane (Doctoral dissertation). Retrieved from ProQuest Dissertations and Theses database. (UMI No 10750341)

[10] Zhu, Y. J., Hu, Y., \& Collins, J. M. (2020). Estimating road network accessibility during a hurricane evacuation: A case study of hurricane Irma in Florida. Transportation research part D: transport and environment, 83, 102334.

[11] Zampieri, N. E., Pau, S., \& Okamoto, D. K. (2020). The impact of Hurricane Michael on longleaf pine habitats in Florida. Scientific reports, 10(1), 1-11. 
[12] Hong, L., \& Frias-Martinez, V. (2020). Modeling and predicting evacuation flows during hurricane Irma. EPJ Data Science, 9(1), 29.

[13] Tomasko, D., Alderson, M., Burnes, R., Hecker, J., Iadevaia, N., Leverone, J., \& Sherwood, E. (2020). The effects of Hurricane Irma on seagrass meadows in previously eutrophic estuaries in Southwest Florida (USA). Marine Pollution Bulletin, 156, 111247.

[14] Benoit, W. L. (1997). Image repair discourse and crisis communication. Public Relations Review, 23, 177-185. doi:10.1016/s0363-811(97)90023-0

[15] Allison, R., Pegoraro, A., Frederick, E., \& Thomas, A.-J. (2019). When women athletes transgress: an exploratory study of image repair and social media. Sports in Society, 1-20. doi:10.108/17430437.2019.1580266.

[16] Wenzel, M., Stanske, S., \& Lieberman, M. B. (2020). Strategic responses to crisis. Strategic Management Journal, 41, 7-18. doi:10.1002/smj.3161.

[17] Ketter, E. (2016). Destination image restoration on Facebook: The case study of Nepal's Gurkha Earthquake. Journal of Hospitality and Tourism Management, 28, 66-72. doi:10.1016/j.jhtm.2016.02.003

[18] Yin, R. K. (2017). Case study research and applications: Design and methods (6th ed.). Thousand Oaks, CA: Sage.

[19] Woods, M., Paulus, T., Atkins, D. P., \& Macklin, R. (2016). Advancing qualitative research using qualitative data analysis software (QDAS)? Reviewing potential versus practice in published studies using ATLAS.it and NVivo, 1994-2013. Social Science Computer Review, 34, 597-617. doi:10.1177/0894439315596311

[20] Mirvis, P. H. (2020). Reflections: US coronavirus crisis management-learning from failure January-April, 2020. Journal of Change Management, 2020(4), 283-311. doi:10.1080/14697017.2020.1836721.

[21] Busby, J. W., Baker, K., Bazilian, M. D., Gilbert, A. Q., Grubert, E., Rai, V., . . W Webber, M. E. (2021). Cascading risk: Understanding the 2021 winter blackout in Texas. Energy Research \& Social Science, 77, 1-10. doi:10.1016/j.erss.2021.102106.

[22] Mirbabaie, M., Bunker, D., Stieglitz, S., Marx, J., \& Ehnis, C. (2020). Social media in times of crisis: Learning from Hurricane Harvey for the coronavirus disease 2019 pandemic response. Journal of Information Technology, 35(3), 195-213. doi:10.1177/02689622092958.

[23] Bui, P. L., \& Wickens, E. (2021). Tourism industry resilience issues in urban areas during COVID-19. International Journal of Tourism Cities, 7(3), 861-879. https://doi.org/10.1108/IJTC-122020-0289

[24] Jiang, Y., Ritchie, B. W., \& Verreynne, M. L. (2019). Building tourism organizational resilience to crises and disasters: A dynamic capabilities view. International Journal of Tourism Research, 21(6), 882-900. https://doi.org/10.1002/jtr.2312

[25] Radic, A., Law, R., Lück, M., Kang, H., Ariza-Montes, A., Arjona-Fuentes, J. M., \& Han, H. (2020). Apocalypse now or overreaction to coronavirus: The global cruise tourism industry crisis. Sustainability, 12(17),

6968. https://doi.org/10.3390/su12176968

[26] Blye, M. L. J. (2020). Reducing the Frequency and Effects of Fraudulent Activities in Community Action Agencies (Doctoral
Dissertation). Retrieved from ProQuest Dissertations and Theses database. (UMI No. 28151060)

[27] Brown, N. A., Rovins, J. E., Feldmann-Jensen, S., Orchiston, C., \& Johnson, D. (2017). Exploring disaster resilience within the hotel sector: A systematic review of the literature. International Journal of Disaster Risk Reduction, 22, 362-370. doi:10.1016/j.ijdrr.2017.02.005.

[28] Luamba, D. (2019). Strategies small business owners use to remain sustainable (Doctoral dissertation). Retrieved from ProQuest Dissertations and Theses database. (UMI No. 13806347)

[29] Lupo, C. V. (2018). Social media marketing strategies in landscape industry small businesses (Doctoral dissertation). Retrieved from ProQuest Dissertations and Theses database. (UMI No. 10809098).

[30] Nguyen, D. N., Imamura, F., \& Iuchi, K. (2017). Public-private collaboration for disaster risk management: A case study of hotels in Matsushima, Japan. Tourism Management, 61, 129140. doi:10.1016/j.tourman.2017.02.003.

[31] Zenker, S., \& Kock, F. (2020). The coronavirus pandemic-A critical discussion of a tourism research agenda. Tourism Management, 81 , https://doi.org/10.1016/j.tourman.2020.104164

[32] Martin, J., \& Joshua, H. (2020). The impact of the new york city marathon on hotel demand. Economies, 8(89), 1-10. doi:10.3390/economies8040089.

[33] Jenssen, J. I., \& Jørgensen, G. (2004). How Do Corporate Champions Promote Innovations? International Journal of Innovation Management, 08(01), 63-86.

[34] Khalifa, G. S. (2020). Factors affecting tourism organization competitiveness: Implications for the Egyptian tourism industry. Africa Journal of Hospitality, Tourism and Leisure, 9(3), 116130. doi:10.46222/ajhtl.19770720-8.

[35] Gupta, P., Doraiswamy, P., Levy, R., Pikelnaya, O., Maibach, J., Feenstra, B., . . . Mills, K. (2018). Impact of California fires on local and regional air quality: The role of a low-cost sensor network and satellite observations. GeoHealth, 2, 172-181. doi:10.1029/2018GH000136.

[36] Kim, Y. (2020). Organizational resilience and employee workrole performance after a crisis situation: Exploring the effects of organizational resilience on internal crisis communication. Journal of Public Relations Research, 32(1-2), 47-75. https://doi.org/10.1080/1062726X.2020.1765368

[37] Moneer, A. (2020). Egypt's image repair strategies in time of crisis: A case study of the Russian Flight Crash. Zeitschrift für Tourismuswissenschaft, 12(2), https://doi.org/10.1515/tw-2020-0002

206-220.

[38] Xu, Z., \& Yan, A. (2020). A pragmatic study of image restoration via corporate apology in Chinese Internet Corporations. English Language Teaching, 13(6), 76-88. http://www.ccsenet.org/journal/index.php/elt

[39] Zakos, K. P. (2021). Violating the racial contract: Black professional athletes and the case of Michael Vick. Howard Journal of Communications, $1-19$. https://doi.org/10.1080/10646175.2021.1971122

[40] Hearit, K. M., \& Roberson, K. M. (2020). Denial, differentiation, and apology: On the use of apologia in crisis management. Handbook of risk and crisis communication, 542559. 
[41] Pereira, V., \& Mohiya, M. (2021). Share or hide? Investigating positive and negative employee intentions and organizational support in the context of knowledge sharing and hiding. Journal of Business Research, 129, 368-381. https://doi.org/10.1016/j.jbusres.2021.03.011

[42] Bizuru, O. K. (2021). A Model of Regime Change: The Impact of Arab Spring throughout the Middle East and North Africa (Doctoral dissertation). http://rave.ohiolink.edu/etdc/view?acc_num=wright1621130268 165228

[43] El-Haddad, A. (2020). Redefining the social contract in the wake of the Arab Spring: The experiences of Egypt, Morocco, and Tunisia. World Development, 127, 104774. https://doi.org/10.1016/j.worlddev.2019.104774

[44] Marsen, S. (2020). Navigating crisis: The role of communication in an organizational crisis. International Journal of Business Communication, 57(2), https://doi.org/10.1177\%2F2329488419882981

163-175.

[45] Stone, M., Erickson, S. L., \& Thorwick, M. (2015). An examination of Pfizer's crisis communication strategies in the Celebrex case. American Journal of Management, 15(1), 11-23. Retrieved from http://www.na-businesspress.com/ajmopen.html

[46] Corazza, L., Truant, E., Scagnelli, S. D., \& Mio, C. (2020). Sustainability reporting after the Costa Concordia disaster: a multi-theory study on legitimacy, impression management, and image restoration. Accounting, Auditing \& Accountability Journal, 8(3), 1909-1941. https://doi.org/10.1108/AAAJ-052018-3488

[47] Forester, J., \& McKibbon, G. (2020). Beyond blame: leadership, collaboration, and compassion in the time of COVID-19. SocioEcological Practice Research,2(3), 205-216. https://doi.org/10.1007/s42532-020-00057-0

[48] Persson-Fischer, U., \& Liu, S. (2021). The impact of a global crisis on areas and topics of tourism research. Sustainability, 13(2),

906. https://doi.org/10.3390/su13020906

[49] Sharma, B., \& Tham, A. (2021). Cultural influences on disaster recovery and impact on tourism: The case of Nepal earthquakes. Journal of New Business Ideas and Trends, 19(1), $1-18$.

[50] Devaraj, J., Ganesan, S., Elavarasan, R. M., \& Subramaniam, U. (2021). A novel deep learning-based model for tropical Intensity estimation and post-disaster management of Hurricanes. Applied Sciences, 11(9), 4129. https://doi.org/10.3390/app11094129

[51] McEntire, D. A. (2022). Disaster response and recovery: strategies and tactics for resilience. John Wiley \& Sons.

[52] Meyer, M. A., Mitchell, B., Purdum, J. C., Breen, K., \& Iles, R. L. (2018). Previous hurricane evacuation decisions and future evacuation intentions among residents of southeast Louisiana. International journal of disaster risk reduction, 31, 1231-1244. https://doi.org/10.1016/j.ijdrr.2018.01.003

[53] Gaur, L., Afaq, A., Singh, G., \& Dwivedi, Y. K. (2021). Role of artificial intelligence and robotics to foster the touchless travel during a pandemic: A review and research agenda. International Journal of Contemporary Hospitality Management, 33(11), 4079-4098. https://doi.org/10.1108/IJCHM-11-2020-1246

[54] Lai, I. K., \& Hitchcock, M. (2017). Sources of satisfaction with luxury hotels for new, repeat, and frequent travelers: A PLS impacts-asymmetry analysis. Tourism Management, 60, 107129. doi:10.1016/j.tourman.2016.11.011
[55] Tsai, C. H., Linliu, S. C., Chang, R. C., \& Mak, A. H. (2020). Disaster prevention management in the hotel industry: Hotel disaster prevention literacy. Journal of Hospitality and Tourism Management, 45, https://doi.org/10.1016/j.jhtm.2020.09.008

[56] Mair, J., Ritchie, B. W., \& Walters, G. (2016). Towards a research agenda for post-disaster and post-crisis recovery strategies for tourist destinations: a narrative review. Current Issues in Tourism, 19(1), $1-26$. doi:10.1080/13683500.2014.932758

[57] Cahyanto, I., \& Pennington-Gray, L. (2015). Communicating hurricane evacuation to tourists: Gender, past experience with hurricanes, and place of residence. Journal of Travel Research, 54, 329-343. doi:10.1177/0047287513517418

[58] Nijkrake, J., Gosselt, J. F., \& Gutteling, J. M. (2015). Competing frames and tone in corporate communication versus media coverage during a crisis. Public Relations Review, 41(1), 80-88. doi:10.1016/j.pubrev.2014.10.010

[59] Ryschka, A. M., Domke-Damonte, D. J., Keels, J. K., \& Nagel, R. (2016). The effect of social media on reputation during a crisis event in the cruise line industry. International Journal of Hospitality \& Tourism Administration, 17, 198-221. doi:10.1080/15256480.2015.1130671

[60] Chan, H. L., Wei, X., Guo, S., \& Leung, W. H. (2020). Corporate social responsibility (CSR) in fashion supply chains: A multi-methodological study. Transportation Research Part E: Logistics and Transportation Review, 142, 102063. https://doi.org/10.1016/j.tre.2020.102063

[61] Chu, S. C., Chen, H. T., \& Gan, C. (2020). Consumers' engagement with corporate social responsibility (CSR) communication in social media: Evidence from China and the United States. Journal of Business Research, 110, 260-271. https://doi.org/10.1016/j.jbusres.2020.01.036

[62] Santos, K. D. S., Ribeiro, M. C., Queiroga, D. E. U. D., Silva, I. A. P. D., \& Ferreira, S. M. S. (2020). The use of multiple triangulations as a validation strategy in a qualitative study. Ciencia and Saude Coletiva, 25, 655-664. https://doi.org/10.1590/1413-81232020252.12302018

[63] Saldana, J. (2016). The coding manual for qualitative researchers (3rd ed.). Thousand Oaks, CA: Sage Publications, Inc.

[64] Dalkin, S., Forster, N., Hodgson, P., Lhussier, M., \& Carr, S. M. (2021). Using computer-assisted qualitative data analysis software (CAQDAS; NVivo) to assist in the complex process of realist theory generation, refinement, and testing. International Journal of Social Research Methodology, 24(1), 123-134. https://doi.org/10.1080/13645579.2020.1803528

[65] O'Kane, P., Smith, A., \& Lerman, M. P. (2021). Building transparency and trustworthiness in inductive research through computer-aided qualitative data analysis software. Organizational Research Methods, 24(1), 104-139. https://doi.org/10.1177\%2F1094428119865016

[66] Swygart-Hobaugh, M. (2019). Bringing method to the madness: An example of integrating social science qualitative research methods into NVivo data analysis software training. IASSIST Quarterly, 43(2), 1-16. https://doi.org/10.29173/iq956

[67] National Oceanic and Atmospheric Administration. (2018). National Oceanic and atmospheric administration: US department of commerce. Retrieved from Extremely active 2017 Atlantic hurricane season finally ends: http://http://www.noaa.gov/ 
[68] Miller, D. S., Gonzalez, C., \& Hutter, M. (2017). Phoenix tourism within dark tourism: Rebirth, rebuilding, and rebranding of tourist destinations following disasters. Worldwide Hospitality and Tourism Themes, 9, 1996-215. doi:10.1108/WHATT-08-2016-0040.

[69] Cordner, S., \& Ellingham, S. (2017). Two halves make a whole: Both first responders and experts are needed for the management and identification of the dead in large disasters. Forensic Science
International,

doi:10.1016/j.forsciint.2017.07.020.

279(1),

60-64.

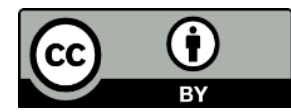

(C) 2021 by the Dr. Kevin C. James, Dr. Dina L. Samora, Dr. Irene A. Williams and Dr. Desire S. Luamba. Submitted for possible open access publication under the terms and conditions of the Creative Commons Attribution (CC BY) license (http://creativecommons.org/licenses/by/4.0/). 